\title{
CAN USING SOCIAL MEDIA AS ONLINE LEARNING PLATFORM INCREASE STUDENT INVOLVEMENT
}

\section{Nurzhynska Anastasiya ${ }^{1}$ \\ Chernobrovkina Vira ${ }^{2}$}

DOI: http://dx.doi.org/10.30525/978-9934-571-27-5_34

Abstract. The use of social media is gradually becoming an integral part of the educational process in higher education institutions. In Ukraine, the most popular for this purpose are Facebook and Twitter, but Instagram is also being increasingly used. This enables not only to introduce the integration element into learning, but also the rapid distribution of teaching materials, almost instant communication with students and attract the maximum number of students to educational projects. Modern education requires the modernization and systematic introduction of new communication technologies in the educational process. It should be noted that the present time dictates its standards and rules not only in the market of media or Internet communications, but also directly applied to the educational process in higher education institutions. It should be noted that the dynamic development of social networks contributed to the development of the teaching and learning process: the development of distance learning in Ukraine, creation of on-line libraries and information repositories, free lessons at certain courses (registration on the university library website and the possibility of round-the-clock access to the course of lectures, student guidelines, textbooks, etc.), systematic on-line communication with the teacher, participation in conferences and webinars. Today, social networks are a server that holds the greatest attention of the consumer audience of different ages.

\section{Introduction}

Social networks today are one of the leading tools in the learning process. This is due to the process of globalization and intensification of information, as well as to a new generation, which absorbs information twice as quickly, needs

\footnotetext{
${ }^{1}$ Postgraduate Student of the Department of Psychology and Pedagogy,

National University of "Kyiv-Mohyla Academy", Ukraine

${ }^{2}$ Doctor of Psychology, Professor,

Professor of the Department of Psychology and Pedagogy,

National University of "Kyiv-Mohyla Academy”, Ukraine
} 
it to be systematically updated and does not understand the concept of "information hunger". It should be noted that the dynamic development of social networks contributed to the development of the teaching and learning process: the development of distance learning in Ukraine, creation of on-line libraries and information repositories, free lessons at certain courses (registration on the university library website and the possibility of round-the-clock access to the course of lectures, student guidelines, textbooks, etc.), systematic on-line communication with the teacher, participation in conferences and webinars. Therefore, there is a need for the constant application of new pedagogical approaches and methods of introduction of teaching material and systematic constant access thereto. At this stage of the development of teaching and learning process, the system requires studying available social tools that are used to build a convenient personal online learning space for student training.

Social networks and servers in the organization of the learning process were studied by such scholars as: Bondarenko E. [11], Ilina O. [20], Hrybiuk O. [19], Osadchyi V. [35], O'Reilly T. [30] and many others. Today, the attention of modern academic circles is focused on the opportunities and benefits of distance learning described in the writings of Stephen Downes and George Siemens.

As an author of the very first Ukrainian online communications course, I believe that online education is extremely important for higher PR-education and it needs more in depth analysis, which I would like to undertake at Stanford University. I would like to study more literature on distance education, modern education tools, higher pedagogy and new approaches within the field of online education that facilitate discussion and critical thinking about communications.

So, these are the major research questions of this project:

How do traditional and online education co-exist in globalpedagogical practice? What are the best examples of integrated courses and why are they so successful?

What could we learn from the Stanfordexperience in online learning tools? What are appropriate case studies in American higher education that can be applicable to Ukraine?

Canonlineeducationimprove the quality of higher media and communications studies?

Can social media replace traditional online learning platforms? Can it increase an involvement of students during the learning process? 


\section{Aim of research}

The research paper aims at studying the peculiarities of the use of social networks during the learning process for student involvement.

\section{Methods of research}

The following methods were used when writing the researhc paper:

- analysis of scientific sources (the opportunity to examine and analyze the existing positions and views of the world and domestic scientists on the stated problem);

- questionnaire survey (gave an opportunity to confirm the research problem in practice, after having learned the real attitude of students and teachers towards social networks in education); processing, analyzing and interpreting the results of the research (which made it possible to find out the real attitude of the Ukrainian lecturers and students to network communications in the pedagogical process and to identify the prospects and ways of further scientific research).

\section{Research findings}

\section{Previous studies and research arguments}

As I mentioned, Facebook has only started to test its online learning feature, which means there is no research available yet on how social media is successfully being used in class rooms. At the same time, Facebook is the most popular social media site and there is no existing data yet if it is an effective teaching tool. So this research will become a show case.This study aims to testFacebook as an online learning tool in class rooms. I will also use the existing studies on active learning, online learning tools, social engagement and innovations in education.

Employability of students, inclusion and accessibility, innovation, and the improvement of education quality [1] are among the main priorities of modern higher education. Social media as an online learning platform can address all these issues.

It should be noted that the present dictates its rules not only in the market of media or on-line communications, but also directly affected the learning process in the higher educational linstitutions. Today, social networks are a server that holds the greatest attention of the consumer audience of different ages. In my opinion, this is a unique communicative platform that synthesizes various forms of communication and enables to 
exchange information and adjust network content without space and time limitations.

Now, there are a number of emerging theories related to the use of social networks and which explain the theory of social learning. It is based on the assumptions that the process of interaction with other students (a group of students) with common subjects within the discipline taught is the most productive for the student in the learning process. Students in groups read up better than alone, which is due not only to social but also to psychological factors. When applying social teaching, a teacher (leacturer) has to deviate a little from the direct content of the curriculum towards exclusively personal interaction in the student group.

\section{Argument 1. Social media contributes to active learning}

The positive effect from active learning in class rooms as compared to traditional lectures has been scientifically proven. A research into educational outcomes of active learning showed much lower failure rates in courses and improved performance in tests. The average failure rate was found to decrease from 34\% (traditional lectures) to $22 \%$ (active learning), whereas performance on identical or comparable tests increased by nearly $50 \%$ [2]. Findings of another study showed that average examination scores improved by about $6 \%$ in active learning sections, and the students in classes with traditional lecturing were 1.5 times more likely to fail than those in active learning classes [3, 4].

Social networks also help students to look for fresh information. In this context, Twitter is a good example [5]. Thanks to access to this resource, students can independently navigate across the information flow. In addition, unlike textbooks and reference books, Twitter contains special tools that help students to determine: what information is relevant and is in demand, and which is not. This social network also allows you to know directly what the world's most famous people think. This is the uniqueness of social networks. All leading scientists and thinkers have their accounts on Twitter or Facebook.

Social media is the source of the qualitative information. Sovereign students are much better informed and equipped than the students ten years ago. Now every child, having a smartphone in his hand, can get the best information, and immediately use it in the lesson. In fact, social media is expanding the choice for students radically [6]. If before (even twenty years ago) the children's opportunities were limited by the library, now, thanks to social networks, they are limitless. 
But at the same time, with a greater number of benefits in introducing social networks and servers in the learning process, there are a number of shortcomings that should be taken into account: this is a non-functional system for finding new friends, a quick addiction to unlimited online presence, a deterioration in health (loss of vision, violation of biorhythm in the body as a result of lack of sleep, nervous system disorder, etc.), communication in virtual networks does not replace human communication as well as real emotions and feelings [7]. Thus, the shortcomings that have a considerable effect on worsening health condition must be taken into account in the formation of educational information environment for training qualified professionals.

\section{Argument 2. Social media use in classrooms boosts student satisfaction}

During the student satisfaction survey, $90 \%$ of respondents agreed with the statement 'I really enjoyed the interactive teaching technique' ( $47 \%$ strongly agreed, $43 \%$ agreed) and only $1 \%$ disagreed. For the statement 'I feel I would have learned more if the whole physics 153 course would have been taught in this highly interactive style' $77 \%$ agreed and only $7 \%$ disagreed [8]. Since Facebook is the most popular social media site among students, so social media in classrooms can improve student satisfaction and involvement.

Downes S. notes that Facebook $[9,10]$ is mostly seen as the leading for the educational process from the standpoint of network psychology. According to scientists, this is due to: first, Facebook allows university lecturers to create a variety of courses for students, and secondly, organizations can create a closed corporate network of employees on the Facebook platform $[11,12]$.

Our days are the beginning of the era of a man with a smartphone [13]. The fact that students and schoolchildren do not part with their phones is not just a school problem. Now, without smartphones, no one is leaving. Nowhere. Almost all business lines have felt it. Even such conservative spheres as golf. Now people with smartphones are everywhere. Now it is the school's turn. Only. In such a situation, it would be wrong to say that students take smartphones to school because of harmfulness. They take them everywhere. Therefore, teachers need to accept this, and start provide their policies in the classroom with the new realities in mind.

The state of satisfaction of students now directly related to the presence of a smartphone. The presence of this device is a guarantee of comfort. 
Staying without a phone means leaving the comfort zone. Many things on which our comfort depends, now mounted in the phone. Even a wristwatch very few people wears.

This year we deseded to make some research and as a university lecturerby I have opened a Facebook group for my students instead of using amoodle platform. Just this summer, Facebook is testing its new online learning feature. As a result, we have already began to integrate it into my classroom learning activities because most of my students are on Facebook most of the time. I've decided that it would be optimal to connect with them there.

A recent edX study says that student attention span is 6.5 minutes. Many students believe "they are the world's best multi-taskers", but "in fact they aren't very good at it", stated Stanford President John Hennessy during the opening dialogue during online learning summit. If online education is to succeed, "you have to make sure you get students to really pay attention to the material" [14]. So I will focus my research at Stanford on using social media as online learning platform to increase student involvement.

For the past four years I have been teaching courses on Public Relations to students of Kyiv Mohyla Academy in Ukraine. But I feel the gap between the traditional teaching style and my students' expectations. During my time at Stanford I will focus in particular on social media and Facebook as online learning tool. This research will contribute to my $\mathrm{PhD}$ dissertation which will explore how online education can help to develop media and communications students' competencies.

Online education is evolving rapidly. In autumn 2011 Stanford University offered three of its courses online free to all applicants. Just one course alone was attended by about 160,000 students from 190 countries. As of June 2014, there were about 2600 such courses in the world - 327\% increase compared to 2013. Today we are witnessing a real revolution in global learning. Online courses are now provided by universities around the world. So Ukrainian pedagogical methodology has to keep up with these changes. As global online education has demonstrated applying digital methods to teaching is highly effective and set an example for Ukrainian education to apply the distance learning technologies. The Ukrainian education sector as a whole has not yet made the transition to programs, curricula and teaching practice that are appropriate to the needs of a new economy and a more explosive labour market [15]. 


\section{Argument 3. Social media can promote accessibility}

Students can access online courses regardless of where they live or what free time they have. Potentially, this can redefine education opportunities for those least well-served in traditional classrooms. Moreover, through the use of AI, online platforms can provide an optimal course pacing and content to fit every student's needs, improving quality of education and learning [16]. Social media can improve accessibility and inclusivity for different student groups.

A website is an automated social environment that allows you to communicate with a group of users who are united by common interest [17]. Consequently, for most modern students studying in higher educational institutions network technologies are already familiar technologies, therefore it is much easier for the lecturer to work, because it is not necessary to teach students to orientate themselves in the space. It promotes the creation of own creative platforms, writing of unique content and the introduction of it in the learning process.

Undeniably, the most popular social networks in Ukraine are Facebook, Twitter and Instagrame. The key feature here is the ability to create groups and communities with specific interests or preferences. Therefore, they are also convenient for the leaturer, since he can create a group and coordinate its activities. In general, when social networks were at the creation and development stages (I mean web 1.0 and web 2.0 platforms), they could only provide opportunities for communication of users, but now we see the expansion of functional and organizational capabilities of social platforms and networks (I mean web 3.0 platform).New opportunities for the learning process are being created, allowing understanding the learning needs of students, to form communications.

Facebook includes a large number of applications that help lecturers and students during the implementation of the learning process. For example, the "weRead" application for reading books that is intended to exchange thoughts about writing or reading, leaving comments, etc. is convenient. The next is Flashcards - an application for flash cards that also carry the educational component. DoResearch 4ME: collects, stores information from brief outline reports to textbooks [18].

Study Groups. The purpose of this application is the introduction and implementation of group projects of both educational and entertaining nature. SlideShare as an application is intended for creating presentations and visu- 
alization of educational material (slideshow). Docs is an application for sharing Word documents. Zoho isan application that allows saving documents on your page and share them with anyone who is interested in this topic [19].

Just as Facebook, Twitter can offer modern students to quickly distribute information as well as comment on events on a real-time basis, being an ideal way for communication for curators of academic groups and courses. Twitter as a social network contributes to the fact that all students of the group can follow the events which are relevant and necessary for their own circle of interests, since this social network is able to narrow the search scope. This social platform can be used not only to read lecture materials, but also to provide substantiation and prompt guidance to students (for example, to those who missed classes or distance learning students and need quick answers and explanations).

Using Twitter, a lecturer has the ability to give a range of tasks to the students that will enhance their skills development. They may include various tasks: from describing events to commenting on situations that have happened in society. Possibility of subscribing for various posts and reposts of Twitter and using hashtags helps to unite students in the network communities [20].

Culatta R. focuses on the fact that social networks are becoming an excellent educational environment capable of providing the educational market with professionals who have acquired knowledge in a comfortable environment [21].

The use of social networks significantly increases the accessibility of education [22]. It is not just about the availability of education for the students themselves. Education (and self-education) is available for everyone who has access to the Internet. This has many effects. Anyone who wants to improve the quality of his or her education can do it free. A huge number of free platforms and educational courses are available on the Internet. Anyone who wants to learn a new profession can do it himself or herself.

The accessibility of education is an even new database for the students themselves. Now it is possible to store all your study materials and manuals online (in the cloud). You can also do this with your notebooks. Now the student can do his homework where he wants and when he wants.

\section{Argument 4. Social media can raise completion rate}

There is also a research that found education quality to drop because of online education. Philosophy professors at San Jose State University argue 
that replacing university courses with free massive open online ones would diminish the quality of education offered to their students [23]. Enrolment to MOOCs is traditionally high, but student retention and completion rates are low. A 2013 study showed that only around 5\% of the students across seventeen Coursera MOOCs completed their studies, and that those who were most successful in this type of online class were the people who had completed higher education, but not those whom MOOCs originally targeted. Therefore, many teachers criticize online learning. It is important to find ways of employing the technology in a manner that helps educators work though. The initiatives that share this view of technology appear to be successful [24].

Foreign scholars (to whom we refer: Deering N., Siegel J., McGuire T.W., Downes S.) argue that, like in social networks, communication in Tweeter is group that makes it mass in nature and attaches maximum transparency to it: those who were not involved in the discussion or event can catch up with the educational material on their own by joining the group, that will greatly save the time of lecturers and students. A continuous feedback helps assess the contribution of each group to the training project $[25,26]$.

It should be emphasized that our contemporary foreign colleagues consider the introduction of social networks (Twitter in particular) as a substitute for the class board, enabling students to independently assess the need for information on the network and placing the necessary resources or advertisements there. Nowadays, lecturers post everything: from homework to advertisements and invitations to master classes. Twipic service is convenient for use, which allows students to upload photos and videos. The relevance of Twit is also due to the fact that there a prize for the most active students regarding academic work may be announced; and this will remove a number of questions regarding the evaluation system. Another very useful applicationin this social network, which is well suited for the educational process is Twitterpole, which facilitates rapid gathering of information about interesting events.

Ehis is a very ambiguous question. It cannot be said that a huge offering of educational products on the Internet is bad. However, the effect (that was shown above) indicates that too much choice can also have bad consequences. Specialists observe the effect of dissipation of attention among students. The more different educational products around, the more difficult it is for students to concentrate their attention on one of them [27]. This applies to both school and general studies. 
This is very strange, but recently, despite the growth of opportunities for education and self-education, there has been no rapid growth in academic performance among students. On the contrary. Because of the power of using the Internet, it is more difficult for students to concentrate on something.

Social networks are becoming a powerful tool in a learning process with a strong potential for development and use. But it's worth noting that in order to use social networks as one of the leading learning tools they should be more and more adapted to the mechanisms of a more flexible and powerful coherent-cognitive interdisciplinary vector for creating educational content that assimilates in the relevant environment and adjusts to its requirements. Here it is worth emphasizing on the quality of implementation, which will be due not only to the quality of student training, but also to the increase of qualifications of the academic staff of higher educational institutions.

\section{Argument 5. Social media can become a key student employability factor}

A major British Council study of university graduate employability found that 'regional employers complain of lack of basic, technical and transferable skills.' In response to this concern, two new university league tables focused on employability sprang up [28]. Social media can help universities meet the employers' expectations.

The dynamic world of the network provoked the development of a wide range of social platforms, which successfully synthesize the communication and the training aspects. Today, a wide range of emerging proposals aimed at the development and implementation of new own social networks. The scholars (Qualman E., O'Reilly T., Charlotte N.) outline some of the leading softwareshere which are worth of more detailed study [29, 30].

A software package for deploying a massive social network that is more focused on the corporate aspect. This is Drupal Commons. This software is based on CMS Drupal, with a free access and, moreover, licensed under GPLv2. A key characteristic here is the availability of training groups consisting of students, lecturers, irregular students and observers. Each of the groups existing there communicates in a particular blog (platform) created specially for it, which contains curricula and programs, list of lecture topics, practical tasks for students, video lectures of lecturers, and there is even a survey function among the group's users. DrupalCommons also acts as a software for the creation of certain communities united by some interesting 
topics. Administrators of such a platform can introduce a system of benefits and privileges to permanent most active users. This platform is free for distribution and easy to use.

The next communication platform which is less user-friendly is called BuddyPress built on the principle of the WordPress platform, which was invented for the organization of own social networks and groups. This technology has recently become widely used and popular. It exists based on the principle of the so-called "add-ons" in WordPress, which facilitates the development of social ties in the blogosphere. As on the previous platform, the leading unifying factor here is the work of friends regarding common needs or interests.

Qualman E. argues that one of the now popular platforms is the so-called Storytlr platform free for communications. Its leading feature is the ability to create micro-blogs and micro-groups, which is convenient for the online learning process. The software is coded in PHP (using the ZendFramework component). Based on this social platform, one can organize not only blogging, but also own scientific library, articles, photo bases, etc. [32] This program is able to integrate with GoogleReader, Picasa, RSS Feeds, Twitter, Vimeo, Youtube, which gives it anopportunity of wide cooperation and joint realization of content.

EurekaStreams is an entire developed media system, which is rightly called social, aiming at implementing and disseminating information within a particular authority or institution. This platform primarily uses the tools for maintaining wiki pages; secondary - blogs and other electronic diaries. This platform allows implementing a software package (both own and collective), creating and posting curricula and guidance for students, as well as tracking interesting topics and events for discussion, thus providing an opportunity of staying in the center of interesting and up-to-date events.

Therefore, it is worth noting that among the named social networks and platforms there are none that would not have passed the stage of dynamic development and did not meet the modern requirements for ensuring informational power, and those that do not meet due to being obsolete either cease to be used or must be updated. The platforms we offered have all the features and options to be introduced into the learning process directly and for application in an expanded learning environment. One of the convenient aspects when using is the parameters of the convenience of organizing the learning process in social networks. These technologies have a number 
of possibilities to facilitate: additional planning, increasing the amount of information material, changing the format (from text to hypertext), etc.

Particular attention should be paid to social servers and their introduction mechanisms, because they are somewhat different means than social networks in our classical sense. Social server is a network tool for creating, storing, and sharing collaborative work on documents of various types [33]. The most popular today are Scribd, Slideboom, Slideschare, Calameo. These resources are intended for storing documents in various formats. A distinctive feature of social networks is that the communication process itself is not leading to them, therefore the communicative task as the leading one is eliminated. The feedback is provided through mutual evaluation and provision of differentiated access to the information field, which is possible only if a certain number of requirements are fulfilled.

A separate group of software consists of the so-called instantaneous information exchange programs (in case of staying on-line), ICQ, Quip, MNS, Miranda, Viber, Telegram. Skype related to voice software [35].

Social networks raise awareness among students about all significant aspects of their lives. The using of social networks can help universities to better understand the demand for education [36]. However, the problem of students employing is not only that universities know little about student co-existence. Unfortunately, the structure of educational courses does not meet the demands of employers. If universities do not reorganize their educational programs, then social networks will not help them.

\section{Argument 6. Social engagement}

Another important research showed that the key to successful education experience is community and social engagement. The completion rate of individuals working alone resembles that of most free open courses on traditional learning platforms. Clearly, basic 'social features' such as discussion boards, messaging, and social network sharing, are insufficient to drive engagement [37]. It can potentially increase importance of using a social media as a communication tool in classrooms.

In order to confirm the idea of high efficiency, we decided to interview lecturers of higher educational institutions in order to find out their attitude to the introduction of social platforms and social networks in the educational and pedagogical process.

The interviewed lecturers (we interviewed 72 lecturers from higher educational institutions of Ukraine: Kyiv International University, Kyiv 
National University of Culture and Arts, Open University of Human Development "Ukraine", Interregional Academy of Personnel Management, Slavic University, Tauric National V.I. Vernadsky University and Information and Creative Agency YUN-PRES) expressed an opinion that social networks are the best for the teaching process cause they provide a function of instant information exchange that allows creating a live communication; those platforms that allow uploading of photos and videos that extends self-descriptiveness of the printed word. It can also be stated that the listed resources have the potential and should be used. 63 lecturers out of 72 use social networks as communication platforms with involvement in the learning process, that is, $91 \%$ of those who use only social networks. Another 51 lecturers (74\%), besides social networks, also use social servers as platforms for learning and posting the necessary volume of educational tasks and materials. And 12 teachers $(22 \%)$ use blogs in line with social networks. Much of the teaching staff is aware of social networks and their capabilities and systematically uses it.

The respondent students noted that now almost 98\% have pages in networks, and 56\% have access and are able to use network servers. Students systematically look in the electronic databases of their groups, considering it is absolutely convenient. $92 \%$ of respondents agreed with this. Another $88.5 \%$ of the students commented that they readily create storages of books, documents, guidelines etc. on their pages, since this is convenient and useful from the position of the learning process, and one can always find the necessary material or task. These data can be found in Table 1.

Having conducted the survey, we confirmed the opinion that today the modern pedagogical process in general, students and lecturers are open to innovative approaches and introductionof the Internet as a communication platform in the educational and pedagogical process understanding its convenience, relevance and necessity.

But at the same time, it can be interpreted that there are a number of characteristics of social networks that should be involved in setting up a pedagogical process on-line.

1. Identify the person. Namely, to know the exact information about it;

2. To see staying on the wersite and the frequency of visits;

3. Understand the process of communication in the network and its strengths/weaknesses (storage of materials, photo/video reports, etc.); 
Table 1

Indicator of the use of social networks as learning platforms by students and leacturers

\begin{tabular}{|l|c|l|c|}
\hline \multicolumn{1}{|c|}{ Indicator } & Lecturers & \multicolumn{1}{c|}{ Question } & Students \\
\hline $\begin{array}{l}\text { Do you use social networks as } \\
\text { communication platforms }\end{array}$ & $\begin{array}{c}\text { Yes } \\
(91 \%)\end{array}$ & $\begin{array}{l}\text { Do you have your own web } \\
\text { page? }\end{array}$ & $\begin{array}{c}\text { Yes } \\
(98 \%)\end{array}$ \\
\hline $\begin{array}{l}\text { Do you use social servers } \\
\text { besides social networks? }\end{array}$ & $\begin{array}{c}\text { Yes } \\
74 \%\end{array}$ & $\begin{array}{l}\text { Do you have access to and are } \\
\text { able to use network servers? }\end{array}$ & $\begin{array}{c}\text { Yes } \\
(56 \%)\end{array}$ \\
\hline $\begin{array}{l}\text { Do you use blogs (or other } \\
\text { platforms) besides social } \\
\text { networks? }\end{array}$ & $\begin{array}{c}\text { Yes } \\
(22 \%)\end{array}$ & $\begin{array}{l}\text { Do you systematically look } \\
\text { in the electronic databases of } \\
\text { your groups, considering it } \\
\text { absolutely convenient }\end{array}$ & $\begin{array}{c}\text { Yes } \\
92 \%\end{array}$ \\
\hline $\begin{array}{l}\text { Are you ready to create } \\
\text { storages of books, documents, } \\
\text { or an entire library on your } \\
\text { pages for the purpose of } \\
\text { providing it to students? }\end{array}$ & $\begin{array}{l}\text { Yes } \\
(85 \%)\end{array}$ & $\begin{array}{l}\text { Are you ready to create } \\
\text { your own storages of books, } \\
\text { documents, or an entire } \\
\text { library on your pages }\end{array}$ & $\begin{array}{c}\text { Yes } \\
(88,5 \%)\end{array}$ \\
\hline
\end{tabular}

Source: the survey was conducted by the author

4. Possibilities to create own mini-groups, which are convenient for a lecturer, and to create own scientific/creative communities.

Students can hardly be successful (even with excellent education), if after graduating from the university they will not have the skills of social communication [38, 39]. Social networks in this regard can be a good help. The use of social networks can significantly help students spread the circle of their social contacts. However, there is also the opposite point of view: communication in social networks cannot replace a full-fledged communication in real life. The number of subscribers cannot be recognize as a number of real friends.

In any case, social networks and communication in this area have already become a reality. Information among students and pupils spreads at a very high rate. It is possible that when the current generation of schoolchildren grows, relations in society will be different then now.

\section{Discussion}

Social services of the Internet turn into the basic means of communication, and the development of social contacts; joint search of information resources and building an information field, storage and editing of information. They also promote the development of creative activity of users in 
the network, and so on. Today, there are a number of scholars who classify social networks into: groups (academic, research, by interests); file sharing (lectures, tasks, programs); publication of materials (video, photo, links to external resources); discussions, polls, alerts, attachments (translator, calculator, stickers, etc.) [34].

The application of social projects and social networks in the learning process is reasoned as follows: free access to the information and library field in Ukraine (up to $78 \%$ according to the statistics), as students readily use various websites to provide themselves with information. Social networks involve more youth projects and websites, and the frequency of logging in social networks is increasing, so there is an overriding advantage here compared with other platforms. The process of learning in the network helps to develop the skills of direct communication and communication with a general public, and the speed of dissemination of information, programs, methodological provision in the learning process provides an opportunity to share experience in communication networks, and provides for the opportunity to be aware of the topic under discussion, even is the class was missed. The systematic interaction in the "student-lecturer" dyad includes the comfort and elimination of personal barriers and aims at continuously updating the information and learning field.

\section{Conclusions}

Having reviewed the existing social networks, we can state that their introduction into the learning process has more advantages than disadvantages.

1. The advantages include: firstly, ease of use, because students got accustomed to their interfaces and secondly, a variety of forms of implementation which may be forums, chats, e-diaries and social networks themselves. A user profile that allows both parties to the learning process to identify the person;

2. The advantages include, also: the opportunity to independently assess the contribution and activity of participants to the learning process, which allows for a more transparent evaluation, and the availability of the communication filter and the possibility of its use during the educational process. The possibility of joint planning of educational subjects and programs of lecturer with students, which makes it possible and facilitates the process of acquiring knowledge and knowledge deepening. 
3. The social networks their introduction into the learning process has the possibility of engaging experts in the field being studied in the study, which makes it even more interesting and deeper, and continuity of learning, which is very convenient for distance learning in particular; ninth, a demonstration of learning material that implements the principle of visibility and realization (the use of video lectures, presentations, photo banks, etc.).

\section{References:}

1. A Renewed EU Agenda for Higher Education: https://ec.europa.eu/education/sites/education/files/investing-youth-he-factsheet_en.pdf and International Trends in Education https://www.ox.ac.uk/sites/files/oxford/International\%20 Trends\%20in\%20Higher\%20Education\%202015.pdf

2. Wieman, Carl E., Large-Scale Comparison of Science Teaching Methods Sends Clear Message PNAS | June 10, 2014 | vol. 111 | no. 23 | 8319-8320.

3. Active Learning Increases Student Performance in Science, Engineering, and Mathematics: http://www.pnas.org/content/111/23/8410.full.pdf

4. Hurevych, R.S. (2015), Formation of the Educational Information Environment For Training Skilled Workers in Technical Vocational Schools: [Monograph]; Ed. by Doctor in Pedagogics, Professor, Corresponding Member of the National Academy of Pedagogical Sciences of Ukraine Hurevych R.S, Planer LLC, Vinnytsia, $426 \mathrm{~s}$.

5. Evans, C. (2014). Twitter for Teaching: Can Social Media be Used to Enhance the Process of Learning? British Journal of Educational Technology, 45 (5), 902-915.

6. Gikas, J., \& Grant, M. M. (2013), Mobile Computing Devices in Higher Education: Student Perspectives on Learning with Cellphones, Smartphones \&Social Media. The Internet and Higher Education, 19, 18-26.

7. Radkevych, O.P.(2015), Confidentiality of Personal Informationof Educators in Vocational Schools duringInformation and Analytical Activity on the Internet // Information and Communication Technology in the Modern Education: Experience, Problems, Prospects: Collection of Scientific Papers, Lviv State University of Life Safety, Lviv, Is. 4, Part 2], Pp. 85-87.

8. Improved Learningin aLarge-EnrollmentPhysicsClass: http://www.math. unm.edu/mctp/gstts/science.pdf

9. Downes Stephen (2012), Connectivism and Connective Knowledge. Essays on meaning and learning networks/ Stephen Downes // Attribution-Non Commercial Share Alike CC BY-NC-SA. - $601 \mathrm{p}$.

10. Wallace, P. (1999), The Psychology of the Internet. - Cambridge: Cambridge Univ. Press.

11. Bondarenko, E., Social Networksas a Development Tool: Types and Oppurtunities. - Electronic Resource. - Retrieved from: http://www.trainings.ru/ library/articles/?id=10067.

12. Annual List Compiled by C4LPT from the Votes of Learning Professionals Worldwide [Electronic Resource] / Top 100 Tools for Learning from Jane Hart Retreived from: http://c4lpt.co.uk/top100tools/guide 


\section{Nurzhynska Anastasiya, Chernobrovkina Vira}

13. Cheston, C. C., Flickinger, T. E., \& Chisolm, M. S. (2013). Social media use in medical education: a systematic review. Academic Medicine, 88(6), 893-901.

14. Campus \& Community, Campus News: Berkeley chancellor, Stanford president kick off online-learning summit, By Public Affairs, UC Berkeley | APRIL 18, 2016: http://news.berkeley.edu/2016/04/18/berkeley-chancellor-stanford-president-kick-off-online-learning-summit/

15. The Education Sector in Ukraine: http://eacea.ec.europa.eu/tempus/participating_countries/higher/ukraine.pdf

16. REPORT Promises and Pitfalls of Online Education Eric Bettinger and Susanna LoebFriday, June 9, 2017: https:/www.brookings.edu/research/promises-and-pitfalls-of-online-education/amp/

17. Shcherbakov, O.V., Shcherbyna, H.A. (2012), Social Network for Support of the Learning Process in Higher Educational Institution // Information Processing Systems: Collection of Scientific Papers / Ministry of Defence of Ukraine, Kharkiv Ivan Kozhedub National Air Force University, Is. 8 (106): Problems and Prospects of the IT Industry Development, Pp. 159-162.

18. Roth, J., Facebook Apps for eLearning [Electronic Resource]. - Retrieved from: http://interactyx.com/social-learning-blog/facebook-apps-for-elearning

19. Hrybiuk, O.O. (2014), Influence of Information and Communication Technologieson Psycho-Physiological Development of Young Generation // "Science", the European Association of Pedagogues and Psychologists. International Scientific-Practical Conference of Teachers and Psychologists "Science of Future": Materials of Proceedings of the International Scientific and Practical Congress. Prague (Czech Republic), the $5^{\text {th }}$ of March, 2014 / Publishing Center of the European Association of Pedagogues and Psychologists "Science", Prague, Vol. 1, 276 p. Pp. 190-207.

20. Ilina, O.M. (2017),Interactive Teaching English to Students of Economic Departms Using Internet Network: Advantages and Disadvantages // Molodyi Uchenyi (Young Scientists) / January 2017, No. 1, Pp. 409 - 412.

21. Culatta R. The Traditional LMS is Dead: Looking to a Modularized Future. [Electronic Resource] - URL: http://www.innovativelearning.com//learning_management/modular-lms.html

22. Davis III, C. H., Deil-Amen, R., Rios-Aguilar, C., \& González Canché, M. S. (2015). Social media, higher education, and community colleges: A research synthesis and implications for the study of two-year institutions. Community College Journal of Research and Practice, 39(5), 409-422.

23. International Trends in Higher Education 2015: https:/www.ox.ac.uk/sites/ files/oxford/International\%20Trends\%20in\%20Higher\%20Education\%202015.pdf

24. Green \& Write Online Schools Deemed Ineffective By Stanford Study November 4, 2015: http://edwp.educ.msu.edu/green-and-write/2015/online-schoolsdeemed-ineffective-by-stanford-study/

25. Dering N. (1999), SozialPsychologie des Internet. - Gцttingen et al.: Hogrefe.

26. Culatta R. The Traditional LMS is Dead: Looking to a Modularized Future. [Електронный ресурс] - URL: http:/www.innovativelearning.com//learning management/modular-lms.html 


\section{Can using social media as online learning platform increase student...}

27. Reasonsto Invite Facebook Into Your Classroom. [Електронний ресурс] URL: http:/www.onlinecollege.org/2011/07/18/50-reasons-to-invite-facebook-intoyour classroom/

28. Škrinjarić, B. (2014). William G. Bowen: Higher Education in the Digital Age. Croatian Economic Survey, 16(1), 171-185.

29. International Trends in Higher Education 2016-17: http://www.ox.ac.uk/ sites/files/oxford/trends\%20in\%20globalisation_WEB.pdf

30. O'Reilly T. What Is Web 2.0: Design Patterns and Business Models for the Next Generation of Soft ware [Electronic Resource] / O'Reilly Tim. - Retrieved from: http://oreilly.com/pub/a/Web2/archive/what-is-Web-20.html?page=1

31. Erik Qualman (2009), Socialnomics: How Social Media Transforms the Way We Live and Do Business. //Wiley, P. 288.

32. Charlotte N. Gunawardena, Mary Beth Hermans, Damien Sanchez, Carol Richmond, Maribeth Bohley \& Rebekah Tuttle (2009): A Theoretical Framework for Building Online Communities of Practice with Social Networking Tools, Educational Media International, 46:1, 3-16 p. [Electronic Resource]. - Retrieved from: http://dx.doi.org/10.1080/09523980802588626

33. Erik Qualman (2009), Socialnomics: How Social Media Transforms the Way We Live and Do Business. //Wiley, P. 288.

34. Bondarenko, E. Social Networks as a Development Tool: Types and Opportunities. - Electronic Resource. - Retrievedfrom: http://www.trainings.ru/ library/articles/?id $=10067$.

35. Osadchyi, V.V. (2012), Social Internet Networks as a Means os Distance Learning / Bulletin of the Post-Graduate Education: Collection of Scientific Papers. University of Education Management of the National Academy of Pedagogical Sciences; Ed. by: O.L. Onufrieva (and others), Is. 7 (20) / Chief Editor V.V. Oliinyk, ATOPOL, Kyiv, Pp. 169.

36. Annual List Compiled by C4LPT from the Votes of Learning Professionals Worldwide [Electronic Resource] / Top 100 Tools for Learning from Jane Hart Retrieved from: http://c4lpt.co.uk/top100tools/guide

37. Frankham, J. (2017), Employability and Higher Education: the Follies of the 'Productivity Challenge'in the Teaching Excellence Framework. Journal of Education Policy, 32(5), Pp. 628-641.

38. Stanford Study Shows Efficacy of Team-Based Online Learning: https://novoed.com/wp-content/uploads/2016/12/NovoEd-White-Paper-ChuckEesley-Engagement-Study-v3-Dec-2016.pdf

39. Quaye, S. J., \& Harper, S. R. (Eds.). (2014). Student Engagement in Higher Education: Theoretical Perspectives and Practical Approaches for Diverse Populations. Routledge. 